UDC 341.225 .13

DOI https://doi.org/10.32841/ILA.2021.25.11

KOVBAN A. V.,

Candidate of Juridical Sciences, Associate Professor,

Associate Professor at the Department of General Legal Disciplines

National University "Odessa Maritime Academy"

\title{
TRENDS OF TRANSFORMATION OF THE CONCEPT OF FREEDOM OF THE HIGH SEAS
}

Summary. The article examines the content of the freedom of the high seas at the present stage of development, the role of the Conventions of the Maritime Law in the formation of the freedom of the high seas as an institution of International Maritime Law and analysis of the results of the Conventions. The author examines current trends in the transformation of freedom of the high seas in modern international Maritime Law. The principle of freedom of the high seas expresses the objective need of States and peoples for the free use of maritime space for international economic, political and cultural ties, as well as for the use of living ocean resources. In 1958, 1960 and 1982, three Conferences on the Maritime Law were held under the auspices of the United Nations.

An important transformation of international cooperation and legislation is also related to the principle of exclusive jurisdiction of the flag state. It means that on the high seas, any ship is subject exclusively to the jurisdiction of the flag State, and no state has the right to interfere in its lawful activities, except as provided by international agreements.

Today, the 1958 Geneva Conventions have mainly historical significance as the embodiment of "traditional Maritime Law", namely the law that existed before the transformations that took place in the international community in recent years. The conventions were adopted in less than a decade. The author argues that in order to maintain order in the open sea and protect its fundamental freedoms, it is necessary to participate not only in leading international organizations, but also in all countries of the world, both coastal and landlocked. Important and effective actions to achieve this goal are the involvement of more states to accede to major international instruments and their implementation into national law. The principle of freedom of the high seas is imperative. This is confirmed by the doctrine of the concept and content of the principles of jus cogens and the provisions of the Vienna Convention on the Law of Treaties of 1969. This is extremely important for maintaining the overall effective regime of maritime space, as a regional rule cannot take precedence over general international law, especially before the norm of jus cogens.

Key words: freedom of the high seas, World Ocean, freedom of navigation, Mare librum, Convention on the Law of the Sea.

Formulation of the problem. Freedom of the high seas (Mare librum) is considered one of the oldest principles of the legal regime governing maritime space, and its main elements were originally freedom of navigation and fishing. Due to the rapid pace of scientific and technological progress, global warming, 
population growth in need of food, activities in the waters of the oceans have gained new momentum, which requires legal regulation.

In 1958, 1960 and 1982, three Conferences on the Maritime Law were held under the auspices of the United Nations. The last Conference ended with the adoption of the UN Convention on the Law of the Sea, which established the legal status of all maritime areas [3].

In connection with the consolidation of new maritime spaces, it is necessary to consider the already well-established concept of international law in the science of the open sea, the freedom of which is increasingly restricted, which arouses interest in research. New trends in the transformation of the institution of freedom of the high seas need further study. In recent decades, the problems of development and use of the oceans have become global in nature, which significantly affects the development of international relations and affects the interests of all countries.

Analysis of recent research and publications. Despite the urgency of the problem of studying the concept of freedom of the high seas, in legal science and international law this issue is given insufficient attention. Problems of determining the principle of freedom of the high seas and its state in modern conditions were studied by such representatives of domestic science of international law as G. Antselevych, O. Shemyakin, V. Goncharenko and others. International legal problems of navigation on the high seas were studied by Y. Bobrova, A. Skaridov, A. Kolodkin, A. Hollik, T. Yomifumi, D. Rothwell and others.

Forming the goals of the article. The purpose and objectives of the study are to clarify the legal nature and legal force of the concept of freedom of the high seas. To achieve this goal, the following main tasks are identified: analysis of the content of freedom of the high seas at the present stage of development; the role of the Conventions on the Maritime Law in the formation and establishment of freedom of the high seas as an institution of international Maritime Law and analysis of the results of the Conventions; study of trends in the transformation of the freedom of the high seas in modern international Maritime Law.

Presentation of the main research. The concept of the "high seas" did not appear immediately. Initially, it was the practice that the coastal state proclaimed its exclusive rights to exploit living marine resources and to navigate in less extensive marine areas adjacent to its shores. The state, which declared any sea as its property, in its territories demanded the subjugation of ships of foreign states, collected duties and brought them under its jurisdiction.

Traditionally, the open sea is the space of seas and oceans that are outside the territorial sea and are not part of the territory of any state. The exclusion of the high seas from the sovereignty of states or groups of states was part of a single historical process, accompanied by the recognition of each state's right to freely use the high seas. This process proved to be long and difficult, and it arose as a result of the needs of states in the implementation of free relations for the exchange of manufactured goods and access to overseas sources of raw materials $[4$, p. 48,109$]$. 
The principle of freedom of the high seas is imperative. This is confirmed by the doctrine of the concept and content of the principles of jus cogens and the provisions of the Vienna Convention on the Law of Treaties of 1969. This is extremely important for maintaining the overall effective regime of maritime space, as a regional rule cannot take precedence over general international law, especially before the norm of jus cogens. The main disadvantage of the 1982 Convention is that its provisions on the need for interstate cooperation in order to conserve the living resources of the high seas (Articles 117-118) are rather vague. There are no precise instructions on how this cooperation should take place. The commitment to cooperate depends entirely on the goodwill of the parties. And if no agreement can be reached, then coastal states have the right to regulate the catch of migratory species exclusively in their economic zone [1, p. 45, 186-190].

P. Gudev notes that the "transformation of sovereignty was that a hierarchical system of concepts was introduced: "sovereign rights", "preemptive law", "zone of jurisdiction". In addition, the Convention enshrines the equal rights of both member states and competent international organizations. That is, in fact, the foundations were laid for the involvement of intergovernmental organizations in the processes of maritime policy [9, p. 54, 174-178].

The framework of national sovereignty has been undermined by the adoption of the concept of the common heritage of mankind. Substantiation of this concept is a problem in international law. After all, in Art. 136 of the 1982 Convention states: "The area and its resources are the common heritage of mankind". However, there is no definition of this concept. If we turn to the authors who study the concept of common heritage, we can analyze the features by which we can characterize the object of international law as belonging to the objects of common heritage of mankind [8]. For example, G. Antselevich explored the following features that can characterize one or another object of international law as an object of the common heritage of mankind, namely: use for the benefit of all mankind, only for peaceful purposes, inadmissibility of national jurisdiction, equality of all peoples for the use of its resources, reasonable fair accounting of the interest of all peoples in the use of resources, the inadmissibility of the assignment of at least one part of the object. At the same time, the author singles out from these features that in practice are characteristic of the waters of the high seas, except for use for the benefit of all mankind and use only for peaceful purposes. Although the 1982 Convention establishes provisions for the use of the high seas only for peaceful purposes, this provision is not mandatory, as military action is carried out in this maritime space [5]. Before the Convention entered into force and the status of the high seas was formally assigned to international waters, the 1958 High Seas Convention stated that "no State may claim the subjugation of any part of the high seas to its sovereignty". Therefore, international waters had the status of "res nullius" and "res communis", their resources and spaces could be used by any state.

Today, the waters of the high seas are formally actively used as an object of the common heritage of mankind, but from the point of view of international 
law they do not have such a status. In general, as noted by foreign authors, the 1982 Convention can rightly be considered the "Constitution of the Seas" in the sense that it is the basis on which to continue the formation of global control over the development and exploitation of space and resources of the oceans. It has led to an increase in the number of treaties and agreements aimed at protecting the marine environment and its biodiversity, acting in their capacity as a so-called legal "umbrella" [19, p. 204-206].

Disputes arise over military activities (for example, anchoring, take-off or landing of aircraft, intelligence gathering, surveillance, reconnaissance). The United States, while not a party to the Convention, insists that military activity is a legitimate use of maritime space, and coastal states have no convention authority to restrict such activity within their exclusive economic zones. In addition, from the position of the United States, the wording of Article 58 of the Convention that "States shall, in the exercise of their rights in the exclusive economic zone, give due consideration to the rights and obligations of the coastal State and comply with the laws and regulations adopted by the coastal State" shall in no way confer additional powers on coastal States, activities of the United States and other countries.

The United States also believes that military research (for example, the collection of oceanographic, geophysical, chemical, biological information for military purposes) does not fall into the category of marine scientific research, and therefore can be easily carried out in the exclusive economic zone of a coastal state [6]. Some states have a fundamentally different view on this issue. For example, the Government of the Republic of Bangladesh, in ratifying the 1982 Convention, stated that its provisions did not entitle other States in the exclusive economic zone to conduct military maneuvers except with the consent of the coastal State.

As mentioned above, with the adoption of the UN Convention on the Law of the Sea, the development of the resources of the ocean floor and subsoil outside the scope of national jurisdiction ceased to be free, it was placed under the control of the International Seabed Authority. In this case, the conflict is due to the fact that thus there was a change in the legal status of these spaces and resources, which for some industrialized countries was economically unacceptable. Since the principle of freedom of the high seas implies that each state has the right to engage in any research or economic activity without any restrictions, each state has the right to launch spacecraft from the high seas. In addition, the 1982 Convention does not prohibit the launch of spacecraft from the high seas. However, the launch of spacecraft from the high seas may not impede the lawful activities of other States in the oceans or international sea routes, the exercise of other freedoms on the high seas. Therefore, the freedom to launch spacecraft on the high seas is exercised in certain areas [10].

The high seas are probably the last region of the world's oceans for which the evolution of international law lags behind the development of economic activity to some extent. Even before the entry into force of the 1982 Conven- 
tion, it was clear that additional measures on military activity, marine industrial fisheries on highly migratory species and transboundary fish stocks, as well as strengthening control over the environmental impact of mining and exploration, could be introduced on the high seas in the near future and energy resources of deep-sea areas. P. Gudev emphasizes that the dialectic of conflict in this area is due to the fact that the freedoms of the high seas are increasingly no longer considered absolute. They are more subordinated not to the national but to the global interests of the entire world community [9]. Both the 1982 Convention itself and other international instruments have transformed the original, centuries-old regime of the high seas.

The Protocol of the Environment (1991) to the Antarctic Treaty is considered to be the first step of the world community towards the establishment of protection zones on the high seas. In the field of shipping control, such areas, including on the high seas, are formed within the framework of the International Convention for the Prevention of Pollution from Ships (MARPOL) [2]. Annex I (Rules for the Prevention of Oil Pollution), Annex II (Rules for the Prevention of Pollution of Harmful Liquid Substances Transported in Bulk) and Annex V (Rules for the Prevention of Pollution from Ship-Waste) of this Convention are aimed at protecting certain areas in maritime areas defined as "special zones".

Paragraph 10 of Regulation 1 of Annex I states that a special area means a sea area where, for recognized technical reasons belonging to its oceanographic and ecological areas and the specifics of navigation, it is necessary to adopt special mandatory methods for preventing marine pollution oil. Such areas were formed in the Baltic, Mediterranean, Black, Red, Arabian, and North Seas, as well as in the Gulf of Aden and Antarctica. It should be noted that many of these areas are outside national jurisdiction. In addition, according to special oceanographic and environmental criteria, as well as shipping characteristics, MARPOL can identify "particularly vulnerable marine areas". It is important to form a JIU under the auspices of the International Maritime Organization. It is assumed that shipping activities may be harmful to the marine environment as a whole and to some areas to a greater extent (operational discharges, accidental or intentional pollution).

This is due to the fact that in accordance with paragraph 4 of Art. 194 of the 1982 Convention, "in taking measures to prevent, reduce or control pollution of the marine environment, States shall refrain from undue interference with the activities of other States in the exercise of their rights and obligations under this Convention".

The issue of naval activity on the high seas remains debatable. Yes, Art. 88 of the Convention states that the high seas are reserved only for peaceful purposes. However, this provision does not affect military maneuvers or the testing of conventional weapons on the high seas. Art. 301 of the 1982 Convention as a whole states in this regard that "in the exercise of their rights and obligations under this Convention, States Parties shall refrain from threatening or using force against the territorial integrity or political independence of any State or otherwise incom- 
patible with the principles of international law embodied in the Charter of the United Nations".

The United States stated that, since the 1982 Convention did not clarify terms such as "peaceful use" and "peaceful purposes", there were no restrictions on the right of States to exercise individual or collective self-defence; wartime, but also in peacetime [7]. This position was formed in 1976 during the Third UN Conference on the Maritime Law. It was that the term "peaceful use" could not be an obstacle to military activity. From the point of view of the United States, the 1982 Convention, being a peacetime agreement, cannot impose any restrictions on military activities or deprive a state of the right to self-defence.

From the point of view of environmental protection, in the most vulnerable areas of the world's oceans there is a need to form special "nuclear-free zones" or zones where any naval maneuvers are prohibited. In the future, we can expect an increase in protests over the trials on the high seas, the resources and spaces of which are increasingly seen as the property of all mankind.

A study of the legal problems of the evolution of freedom of fishing on the high seas, an analysis of the provisions of the 1982 UN Convention on the Law of the Sea, the national legislation of individual coastal states governing fishing in coastal areas, led to a number of conclusions. First, the principle of freedom of fishing on the high seas arose, formed and affirmed as an element of a more generalized principle - the principle of freedom of the high seas. For a long time, it remained a customary rule of law, and with the adoption of the Geneva Convention on the High Seas in 1958, it became a treaty rule. Secondly, the freedom of fishing on the high seas is not unlimited. It is governed by many international agreements, including the provisions of the 1982 United Nations Convention on the Law of the Sea. In other words, the principle of freedom of fishing at present can most likely be called the principle of rational (scientifically sound) fishing on the high seas. Third, due to the establishment of 200-mile coastal zones by states, the spatial limit of the principle of freedom of fishing on the high seas has been significantly limited. Currently, it extends only to parts of the high seas outside these areas.

Practical directions of development of the conventional regime on the high seas are: fight against pollution of the marine environment; protection and conservation of living resources of the oceans; conservation of biological diversity. No one doubts that the pollution of the marine environment is a global negative trend and today no area of the world's oceans can be considered in which there is no such trend.

Given the crucial role of space and resources of the oceans for all mankind, as well as the interdependence between the states of an ecosystem, the growth of pollution requires urgent and adequate measures.

The 1982 Convention identified 6 sources of pollution of the marine environment: pollution from land-based sources; pollution caused by seabed activities; pollution caused by activities in the International Seabed area; pollution caused by burial; pollution from ships; pollution from the atmosphere 
and through it. Priority should be given to preventive measures. At the same time, self-defence measures aimed at protecting ships from acts of piracy and other acts of armed attack on ships need to be improved, as it is difficult to create an environment of full security for ships in different parts of the oceans, but they often become completely vulnerable to armed attacks. Criminals know this and this is one of the conditions that contribute to the commission of such crimes. As in the case of the protection of ships from terrorist acts, measures of self-defence of ships may be carried out by members of the "self-defence team" only if the resolution of known legal problems.

It should also be noted that the absence of weapons on ships does not preclude the use of force against pirates by members of the ship's crew. Meanwhile, during the implementation of force in self-defence of the ship from pirate attacks, the following interrelated problems arise. On the one hand, resistance to pirates can lead to casualties among the crew and passengers of the ship, and on the other - in its absence, the unknown consequences after the departure of criminals from the ship (destruction of passengers and crew as witnesses, other dangerous consequences).

According to experts, preparations for action in case of piracy should be carried out taking into account the provisions of the plan to prevent pirates from entering the deck. The plan should include a set of measures to combat pirates in preparation for the passage of a dangerous area, when pirates are detected on the approaches to the ship, as well as in case of their breakthrough on deck (maintenance in readiness for immediate use of fire barrels; that can be used by pirates to board a ship, etc.) [8].

The role of cooperation between coastal states in troubled regions is also important. For example, Malaysian maritime organizations believe that the best and most effective way to combat piracy would be to engage the police and naval forces of coastal states to regularly patrol the most dangerous areas of the sea.

In order to maintain order in the open sea and to protect its fundamental freedoms, it is necessary to involve not only the leading international organizations, but also all countries of the world, both coastal and landlocked. Important and effective actions to achieve this goal are the involvement of more states to accede to major international instruments and their implementation into national law.

Conclusions and prospects for further research. The adoption of the four conventions meant that the unity of the Maritime Law was lost, but there may be advantages, such as the adoption of conventions and a single protocol instead of a single legal act, trying to involve more states in at least some of the conventions, avoided a large number of radical reservations. Today, the 1958 Geneva Conventions have mainly historical significance as the embodiment of "traditional Maritime Law", namely the law that existed before the transformations that took place in the international community in recent years. The conventions were adopted in less than a decade. However, despite their legal quality, they were quickly perceived by most states as obsolete. The Third United Nations Conference on the Maritime Law lasted from 1973 to 1982 . However, as a result of eleven sessions 
held in various parts of Europe and the United States, a single United Nations Convention on the Law of the Sea was adopted on 10 December 1982.

The non-participation of the United States in the 1982 Convention significantly undermines the established conventional water regime. All this in combination underestimates the universally binding nature of the 1982 Convention, which provokes a future increase in the number of legal disputes and threatens the existing legal order in the world's oceans.

Active work is under way to develop an agreement on the protection of marine biological diversity outside areas of national jurisdiction, including through the establishment of marine protected areas in the high seas. The International Maritime Organization and the Food and Agriculture Organization of the United Nations will influence the formation of International Maritime Law, the interpretation and implementation of certain provisions of the 1982 Convention.

\section{References:}

1. Yoshifumi T. The International Maritime Law. New York : Cambridge University Press, 2012. 672 p.

2. Международная конвенция по предотвращению загрязнения с судов 1973 года, изменённая протоколом 1978 г. к ней: МАРПОЛ 73/78: В 2 кн. Санкт-Петербург, Кн. 1: Конвенция, протоколы к ней с дополн. 1994. 313 с.

3. Конвенція Організації Об'єднаних Націй 3 морського права 1982 року. / Верховна Рада Украӥни. База даних «Законодавство Украӥни». URL: https://zakon.rada.gov.ua/laws/main/995_057.

4. Авраменко И.М. Международное морское право. Ростов-на-Дону : Феникс, $2001.448 \mathrm{c}$.

5. Анцелевич Г.А. Международно-правовой статус и режим пользования морских объектов общего наследия человечества. Перспективы развития в порядке de lege feranda : монография. Киев, 2002.360 c.

6. Kraska J. Maritime Power and the Maritime Law. Expeditionary operations in World Politics. New York: Oxford University Press, 2011. 400 p.

7. Senate Executive Report, 110h Congress, 1st Session, Exec. Rpt. 110-9. URL: http://www.gc.noaa.gov/documents/UNCLOS-Sen-Exec-Rpt-110-9.pdf.

8. Ушаков А.В. Піратство як чинник, що порушує свободу відкритого моря і перешкоджає формуванню його міжнародно-правового статусу як об'єкта загальної спадщини людства. URL: http://zt.knteu.kiev.ua/files/2013/3(68)/ uazt_2013_3_16.pdf.

9. Гудев П.А. Конвенция ООН по морскому праву: проблемы трансформации режима. Москва : ИМЭМО РАН, 2014. 201 с.

10. Кожевникова П.К. Правовое регулирование проведения запусков космических аппаратов из открытого моря. Актуальные проблемь авиации и космонавтики. 2015. Т. 2. 455 с.

Ковбан А. В. Тенденції трансформації концепції свободи відкритого моря

Анотація. У статті досліджується зміст свободи відкритого моря на сучасному етапі розвитку, роль Конвенцій з морського права у формуванні та становленні свободи відкритого моря як інституту міжнародного морського права та аналіз результатів Конвенцій. 
Автор досліджує сучасні тенденції трансформації свободи відкритого моря у сучасному міжнародному морському праві. Принцип свободи відкритого моря виражає об’єктивну необхідність держав та народів у вільному використанні морських просторів для здійснення міжнародних економічних, політичних та культурних зв'язків, а також використання живих ресурсів океану. У 1958 р., 1960 р. та 1982 р. під егідою Організації Об’єднаних Націй було проведено три Конференції з морського права.

Важлива трансформація міжнародного співробітництва та законодавства пов'язана також з принципом виключної юрисдикції держави прапора. Це означає, що у відкритому морі будь-яке судно підпорядковується виключно юрисдикції держави прапора, і жодна держава не має права втручатися в його законну діяльність, крім випадків, передбачених міжнародними угодами.

Натепер Женевські конвенції 1958 р. мають, головним чином, історичне значення як втілення «традиційного морського права», а саме такого права, яке існувало до трансформацій, що відбулися в міжнародному співтоваристві останніми роками. Конвенції були прийняті менш ніж за десятиліття. Автор стверджує, що для підтримання порядку у просторах відкритого моря та захисту його основних свобод, необхідна участь не лише провідних міжнародних організацій, а й усіх держав світу як прибережних, так і тих, що не мають виходу до моря. Важливими та ефективними діями для досягнення цієї мети $\epsilon$ залучення більшої кількості держав для приєднання до основних міжнародних актів та їх імплементація в національне законодавство. Принцип свободи відкритого моря $\epsilon$ імперативним. Це підтверджується доктриною, що стосується поняття і змісту принципів jus cogens, та положеннями Віденської конвенції про право міжнародних договорів 1969 р. Це має винятково велике значення для збереження загалом дієвого режиму морських просторів, оскільки регіональна норма не може мати переважної сили перед нормою загального міжнародного права, тим більше перед нормою jus cogens.

Ключові слова: свобода відкритого моря, Світовий океан, свобода судноплавства, Mare librum, Конвенція з морського права. 